\title{
Subcutaneous emphysema pada anak kucing kampung
}

\author{
Yulia Erika* \\ Klinik Hewan Zech Vet Care, Rawang, Padang Selatan, Padang, Sumatera Barat INDONESIA
}

\begin{abstract}
ABSTRAK: Subcutaneous emphysema jarang terjadi pada kucing dan tergolong kasus langka. Tulisan ini melaporkan kejadian kasus pada anak kucing kampung berusia kurang lebih 3 bulan dengan gejala akumulasi gas di tubuh. Pemeriksaan klinis dan radiografi dilakukan untuk diagnosa penunjang pada kasus subkutan emfisema. Terapi dilakukan dengan membuat sayatan pada kulit sebagai jalan evakuasi udara, dilanjutkan dengan pemberian antibiotik, antiinflamasi, dan suplemen. Satu hari pascaterapi, anak kucing kampung kondisi tubuh sudah kembali normal, dapat defekasi dan grooming secara mandiri.

Kata kunci:

anak kucing kampung, akumulasi udara, subkutan.
\end{abstract}

\section{- PENDAHULUAN}

Emfisema subkutan (Subcutaneous emphysema) adalah temuan klinis yang jarang terjadi pada kucing. Akumulasi gas bebas pada tubuh dapat terjadi secara spontan ketika gas/udara menyusup dari organ internal seperti paru-paru, atau organ luminal lainnya seperti orofaring, laring, trakea, tabung bronkial, esofagus atau bahkan kolon. Juga dapat terjadi sebagai akibat dari faktor traumatis atau infeksi (Brockman et al. 2004). Trauma seperti tertabrak kendaraan, terkena tembakan, gigitan luka pada abdominal/perut dan pneumotoraks iatrogenik/kesalahan medis (Mason et al. 2000). Tulisan ini bertujuan untuk menambah laporan kasus agar dapat berbagi kasus-kasus langka yang jarang ditemukan pada praktik hewan kecil.

\section{- KASUS}

Anamnesa dan siyalemen: Anak kucing kampung betina berusia sekitar 3 bulan ditemukan 3 hari sebelumnya dalam kondisi badan penuh gas, terasa sangat ringan seperti balon yang berisi udara (Gambar 1). Nafsu makan masih baik. Urinasi normal, tetapi belum ada defekasi sejak 2 hari paska diselamatkan. Pemeriksaan fisik: Akumulasi gas/udara mengisi hampir $90 \%$ tubuh, kecuali area bagian ekor, dan ekstremitas bawah (tarsal, metatarsal, dan phalangs). Keberadaan pinjal sangat banyak. Terdapat krepitasi subkutan saat palpasi dilakukan dengan penekanan lembut pada kulit. Pemeriksaan penunjang: Radiografi diambil di RSH Sumatera Barat sebelum dirujuk ke klinik (Gambar 2). Diagnosa: Subcutaneous emphysema. Prognosa: Fausta. Terapi dan Penanganan: Insisi pada kulit sebagai jalan evakuasi udara, lalu dilakukan pemijatan untuk mendorong udara agar keluar. Sediaan antibiotik, antiinflamasi, dan suplemen diberikan selama 3 hari pengobatan.

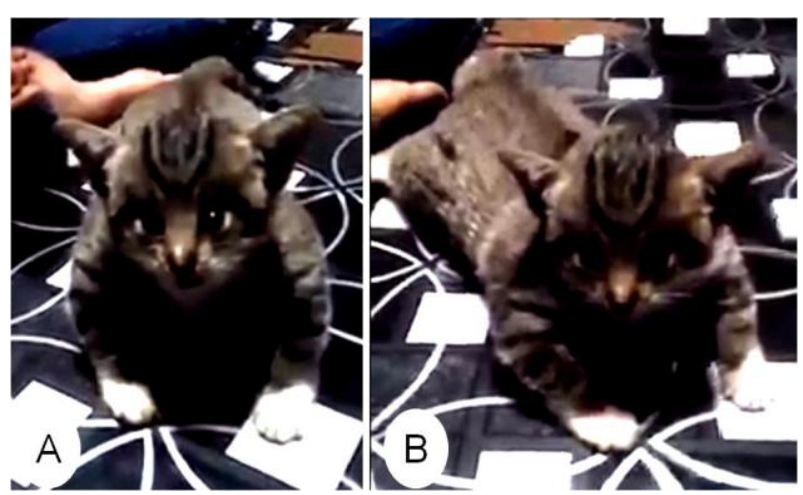

Gambar 1. Kucing yang mengalami akumulasi udara pada tubuh. (A) tampak depan, dan (B) tampak serong.

\section{- HASIL DAN PEMBAHASAN}

Subcutaneous emphysema adalah salah satu kasus yang jarang terjadi pada kucing, tergolong sebagai kasus langka. Kasus ini umumnya disertai penumomediastinum yang dapat terjadi karena intubasi traumatis, overinflasi tube endotrakeal, ventilasi tekanan positif, prosedur pencucian trans-trakea, dilatasi kerongkongan dan venipuncture jugularis (Hassan et al. 2015). Ketika mediastinum terhubung dengan jaringan subkutan di leher melalui lubang masuk dada dan dengan retroperitoneum melalui hiatus aorta, udara menyebar sehingga menyebabkan emfisema subkutan dan/atau pneumoperitoneum (Itoh et al. 2005).

Subcutaneous emphysema umumnya aterjadi kibat trauma pada jaringan lunak dan dapat juga disebabkan oleh infeksi bakteri anaerob (Rajan 2014). Udara yang keluar dari rongga dada dapat menyusup ke jaringan subkutan di daerah kepala dan leher. Hasil palpasi anak kucing pada kasus yang ditangani pada daerah abdomen, teraba distensi

Diterima: 23-04-2019 | Direvisi: 27-04-2019 | Disetujui: 03-05-2019 (C) 2019 CC-BY-SA. Ini adalah artikel Open Access yang didistribusikan berdasarkan ketentuan dari Creative Commons Attribution ShareAlike 4.0 International License (https://creativecommons.org/licenses/by-sa/4.0/). 
yang ditandai dengan bunyi krepitasi berbeda. Distensi ini menghambat palpasi organ abdomen, saat diketuk terdengar suara seperti drum timpani. Suara timpani meluas ke dada dan leher yang mengindikasikan adanya emfisema subkutan secara umum.

Hasil pemeriksaan kasus ini ditemukan luka di bagian kaki depan sebelah kanan sedikit di atas prescapular pada anak kucing. Infeksi dapat menyebabkan udara masuk melalui luka. Hasil pengujian lanjut melalui pencitraan radiografi terlihat dinding dada mengalami distensi kulit regio toraks yang berlebihan sehingga terlihat seperti balon yang menggelembung (Gambar 2). Radiografi regio abdomen juga tampak adanya akumulasi gas dalam jumlah yang luar biasa besar sehingga terjadi tekanan berlebihan pada rongga abdomen.
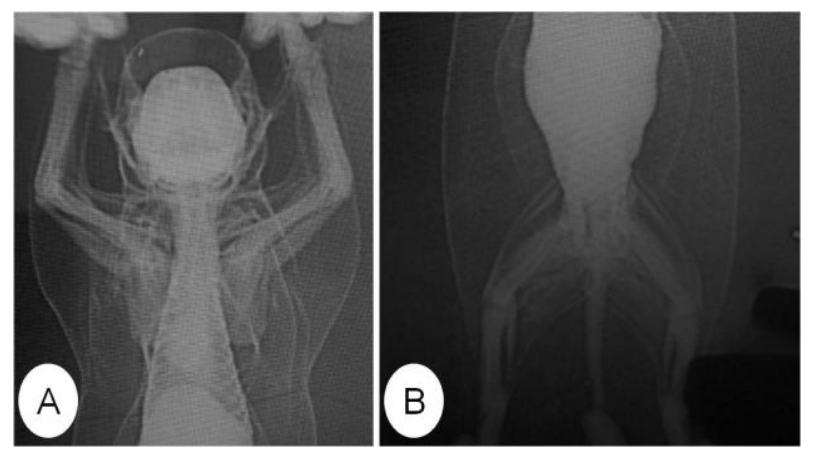

Gambar 2 Radiografi pada anak kucing posisi ventrodorsal. (A) regio dada, dan (B) regio abdomen.

Pemulihan kucing dari gas yang terjebak ini dapat berlangsung dengan sendiri, akan tetapi pada kasus yang komplikasi perlu dilakukan tindakan lebih lanjut. Udara yang terperangkap pada jaringan subkutan dapat dikeluarkan dengan membuat insisi pada kulit sepanjang kurang lebih 1 $\mathrm{cm}$. Antibiotik (amoxicilin injeksi, metronidazole oral), antiinflamasi (beazyme/papain enzyme), dan suplemen (multi nutrient formula) diberikan untuk mencegah infeksi, peradangan berlebih dan mendukung proses persembuhan hingga beberapa hari ke depan.
Kondisi anak kucing sebelum terapi memiliki berat badan \pm 4 ons ( \pm 400 gram). Bobot badan ana kucing meningkat 1 ons setelah dilakukan terapi pengeluaran udara sebanyak hampir $70 \%$ dari kondisi sebelumnya total gas $90 \%$. Nafsu makan anak kucing juga membaik (Gambar 3), dan kucing dapat melakukan defekasi 3 hari pascaterapi.
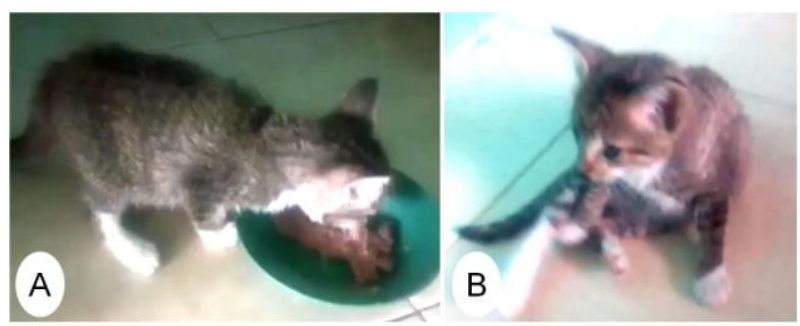

Gambar 3 Perkembangan kondisi anak kucing setelah 3 hari pascaterapi. (A) kucing makan secara lahap, dan (B) kondisi tubuh menjadi normal kembali.

\section{- SIMPULAN}

Emfisema subkutan dapat didiagnosa dengan mudah melalui diagnosa penunjang radiografi dan dapat ditangani secara langsung melalui tindakan pengeluaran udara.

\section{- INFORMASI PENULIS}

Penulis untuk Korespondensi

*YE: yuliaerika@ rocketmail.com

Zech Vet Care, J1 Sutan Syahrir, Simpang Ikal, Komplek TBO, Blok D/2, Rawang, Padang Selatan, Padang, Sumatera Barat INDONESIA, Kode pos 25216

\section{- PUSTAKA ACUAN}

Brockman DJ, Puerto DA. 2004. Pneumomediastinum and Pneumothorax. In: Textbook of Respiratory Disease in Dogs and Cats, King, L.G. (Ed.). 1st Edn., Chapter 82, Saunders: USA. pp 616-624.

Hassan EA, Torad FA, Shamaa AA. 2015. Pneumopericardium secondary to pneumomediastinum in a golden retriever dog. Top. Companion Anim. Med., 30(2): 62-64.

Itoh T, Nibe K, Naganobu K. 2005. Tension pneumoperitoneum due to gastric perforation in a cat. J. Vet. Med. Sci., 67(6): 617-619.

Mason NJ, Michel KE. 2000. Subcutaneous emphysema, pneumoperitoneum and pneumoretroperitoneum after gastrostomy tube placement in a cat. J. Am. Vet. Med. Assoc., 216(7): 1096-1099.

Rajan SK. 2014. Subcutaneous emphysema and pneumomediastinum in kitten-a rare case report. Int. J. Agric. Sci. Vet. Med., 2: $135-138$. 